\title{
Keefektifan metode role playing untuk penanaman nilai-nilai Pancasila pada pembelajaran Pendidikan Kewarganegaraan
}

\author{
Uwi Martayadi *, Marzuki Marzuki \\ Program Studi Pendidikan IPS, Pascasarjana, Universitas Negeri Yogyakarta. \\ Jalan Colombo No. 1, Karangmalang, Yogyakarta 55281, Indonesia \\ uwimartayadi@gmail.com \\ * Corresponding Author
}

\section{ARTICLE INFO}

\section{Article History}

Received:

25 November 2015;

Revised:

19 August 2019;

Accepted:

24 September 2019

\section{Keywords}

Permainan peran;

Pancasila:

Pendidikan

Kewarganegaraan;

Role playing;

Civic education;

\begin{abstract}
ABSTRAK
Penelitian ini bertujuan untuk mendeskripsikan: 1.) Keefektifan metode role playing untuk penanaman nilai-nilai Pancasila pada pembelajaran Pendidikan Kewarganegaraan; 2.) Keefektifan metode konvensional untuk penanaman nilai-nilai Pancasila pada pembelajaran Pendidikan Kewarganegaraan; dan 3.) Pembelajaran yang lebih efektif antara kedua metode tersebut. Penelitian ini adalah penelitian eksperimen semu. Subjek penelitian ini adalah 32 peserta didik kelas VIII B SMP Muhammadiyah 3 Kota Yogyakarta (kelas eksperimen) dan 30 peserta didik kelas VIII A SMP Muhammadiyah 4 Kota Yogyakarta (kelas kontrol), sehingga keseluruhan subjek berjumlah 62 peserta didik. Pengumpulan data menggunakan angket dan tes. Uji validitas dengan expert judgement. Teknik analisis data yang digunakan adalah deskriptif dan uji MANOVA. Hasil analisis data dengan uji MANOVA menunjukkan bahwa: 1.) Metode role playing efektif untuk penanaman nilai-nilai Pancasila pada pembelajaran Pendidikan Kewarganegaraan dengan melihat kelompok eksperimen sebelum percobaan, nilai $\mathrm{T}$ untuk prestasi 2,731 sig 0.005 , nilai-nilai Pancasila $\mathrm{T}$ $6,069 \mathrm{sig} 0,000 ; 2$.) Metode konvensional efektif untuk menanamkan nilai-nilai Pancasilal, nilai prestasi T 0,045 sig 0,482, nilai-nilai Pancasila T 4,12 sig 0.000; dan 3.) metode role playing lebih efektif dibandingkan dengan metode konvensional untuk penanaman nilai-nilai Pancasila pada pembelajaran Pendidikan Kewarganegaraan setelah melakukan pengujian dengan value 1,020, F 30.089, dan sig 0,000.
\end{abstract}

The research aims to describe: 1.) The effectiveness of the role playing method in inculcating the values of Pancasila in civic education teaching; 2.) The effectiveness of the conventional method in inculcating the values of Pancasila in civic education teaching; and 3.) The more effective one between the two methods. This research is quasi experiment. The subject of this reserch is 32 grade VIII B students of Junior High School 3 Muhammadiyah in Yogyakarta City (the experimental class) and 30 grade VIII A students of Junior High School 4 Muhammadiyah in Yogyakarta City (the control class). So that the whole subject amounted to 62 students. The instrument of data collection was aquestionnaire and tests. The expert judgemen was used to reveal the validity of the instruments. The data analysis used the descriptive analysis and Multivariate Analysis of Variance. The result of the data analysis based on MANOVA test shows that: 1.) The role playing method is effective to inculcate the values of Pancasila in civic education teaching in the experimental class before the treatment with the score of t-test for students' achievement being 2.731 at the significance level of 0.005, for Pancasila 6.069 at the significance level of 0.000; 2.) The application of the conventional method is effective in inculcating the values of Pancasila in civic education teaching in which the score of t-test of students' achievment was 0.045 at the significance level of 4.82 and for Pancasila was 4.12 at the significance level of $0.000 ; 3$.) the application of the role playing method is more effective than the conventional method to inculcate the values of Pancasila in civic education teaching after the last was done, in which the score was 1.020, F was 30.089 at the significance level of 0.000 .

This is an open access article under the CC-BY-SA license.

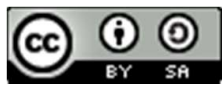




\section{PENDAHULUAN}

Pendidikan merupakan salah satu indikator maju mundurnya suatu bangsa, kualitas sumber daya manusia juga tergantung pada pendidikan. Oleh karena itu, pendidikan mempunyai peranan yang sangat penting di dalam membentuk kepribadian peserta didik atau generasi muda, mencerdaskan kehidupan bangsa, dan sebagai media untuk mempertahankan nilai-nilai luhur Pancasila. Eksistensi Pancasila sebagai dasar negara, mendapat perhatian serius dari masyarakat. Berbagai pendapat negatif bermunculan terkait dengan Pancasila yang perlu diluruskan agar tidak menimbulkan ketimpangan-ketimpangan yang bisa memecah belah persatuan dan kesatuan masyarakat Indonesia (Hamidi \& Lutfi, 2010, p. 51). Nilai-nilai dasar yang terkandung di dalam Pancasila di antaranya, nilai ketuhanan, kemanusiaan, persatuan, kerakyatan, dan keadilan. Hamidi \& Lutfi (2010, p.55). Dewasa ini, peserta didik ataupun generasi muda semakin tidak peduli pada nilai-nilai Pancasila serta kurang memahami sejarah bangsanya sehingga rasa nasionalisme, patriotisme, cinta tanah air, dan tanggung jawab terhadap masyarakat diabaikan begitu saja. Presiden Republik Indonesia yang pertama Ir. Soekarno pernah mengatakan "Jas Merah", yang artinya jangan pernah melupakan sejarah. Maksud dari ungkapan tersebut adalah bahwa sebagai generasi muda harus memahami sejarah bangsa agar bisa bercermin (belajar) dari peristiwa masa lalu, yang kurang diperbaiki dan yang baik dipertahankan serta ditingkatkan (Putra, 2010, p. 3).

Penanaman nilai-nilai Pancasila pada peserta didik perlu diwadahi melalui pendidikan formal dan nonformal.Pendidikan Kewarganegaraan (PKn) merupakan wadah yang tepat untuk memberikan pemahaman pada peserta didik tentang pentingnya Pancasila sebagai dasar negara serta penanaman nilai-nilai yang terkandung di dalamnya untuk menjaga keutuhan bangsa dan negara Indonesia. Peserta didik akan menjadi warga negara Indonesia yang cerdas dan berkarakter manakala pendidikan dalam keluarga, sekolah, dan masyarakat saling mendukung dalam mengajarkan PKn. Salah satu faktor penunjang dari keberhasilan pembelajaran PKn adalah penggunaan metode pembelajaran yang tepat. Metode merupakan sesuatu yang penting karena berhasil tidaknya proses belajar mengajar sangatlah ditentukan oleh efektivitas metode yang digunakan oleh guru dalam menyampaikan informasi pembelajaran. Oleh karena itu, metode pembelajaran yang digunakan haruslah menarik dan melibatkan peserta didik dalam proses pembelajaran, sehingga peserta didik tidak merasa bosan dan tidak mudah melupakan materi yang diajarkan.

Nilai-nilai Pancasila tersebut merupakan nilai inti yang harus dipertahankan dan dilestarikan oleh warga negara Indonesia. Setiap sila mengandung nilai atau makna yang sangat mendalam, seperti sila ketuhanan merupakan pemaknaan terhadap nilai-nilai religius yang berkaitan antara indivindu dengan Tuhan. Sila kemanusiaan berhubungan dengan aspek moralitas, keteraturan, dan perwujudan pranata sosial yang beradab. Sila persatuan Indonesia menyiratkan makna perwujudan kesatuan dan kasih sayang terhadap segenap suku bangsa dari Sabang sampai Merauke. Sila Permusyawaratan dan Perwakilan menyiratkan makna perlunya demokrasi atas dasar konsensus dalam menyikapi berbagai persoalan. Dan sila keadilan sosial yang menyiratkan perilaku yang transparan, adil, dan merata guna mewujudkan kesejahteraan sosial bagi seluruh rakyat Indonesia (Calm \& Sobirin, 2012, p. 98). Namun, seiring dengan berjalannya waktu penyimpangan terhadap nilai-nilai Pancasila banyak dilakukan oleh rakyat Indonesia, sebagaimana dijelaskan Romli (2012) bahwa Indonesia telah memiliki Pancasila yang menjadi civil religion atau public ethic bangsa. Namun, akhir-akhir ini, Pancasila disebut-sebut tidak lagi memiliki ruh yang mampu menggerakkan semangat kebersamaan warga negara baik dalam konteks bernegara, berbangsa, dan bermasyarakat. Pernyataan tersebut menunjukkan bahwa nilai-nilai Pancasila banyak yang dilanggar dan tidak diamalkan, Pancasila hanya sekedar diucapkan secara lisan saja tetapi implementasi dalam kehidupan sehari-hari sudah mulai pudar serta cenderung dilanggar. Hal ini relevan dengan pernyataan Kaelan dalam Sukadi (2010, p. 264) yang menyatakan bahwa banyak kalangan anggota masyarakat dewasa ini dinilai tidak lagi mencerminkan komitmennya yang kuat dalam mengamalkan secara kontekstual nilai-nilai Pancasila sebagai ideologi nasional dalam kehidupan bermasyarakat, berbangsa, dan bernegara Indonesia.

Pernyataan Kaelan tersebut menunjukkan bahwa komitmen masyarakat sudah mulai pudar terhadap pengamalan nilai-nilai Pancasila. Hal ini disebabkan karena pengaruh globalisasi yang tidak bisa disaring dengan baik oleh diri pribadi maupun pemerintah. Akibatnya banyak masyarakat yang 
bersifat indivindual, tidak perduli terhadap sesama, dan rasa gotong royong (kebersamaan yang sudah mulai diabaikan). Amir (2013, p. 54) memiliki pandangan yang sejalan dengan Kaelan yang menyatakan:

The influence of the ideology of neo-liberalism with a set of values such as individualism, materialism, secularism, hedonism, rationalism, materialism, the high of consumerism culture and the effect of market culture with the values of capitalism has hit the Indonesian national identity with a democratic political life, so that we as a nation of Indonesia almost forgotten the values of its own local culture and religion which we believe.

Hari Selasa tanggal 3 September 2014 penulis melakukan wawancara dengan guru PKn SMP Muhammadiyah 4 Kota Yogyakarta dan menyatakan bahwa mata pelajaran PKn kurang menarik. Hal ini dikarenakan guru tidak memvariasikan metode dalam mengajar. Guru hanya menggunakan metode ceramah dan tanya jawab dalam proses pembelajaran (konvensional). Guru perlu memperkenalkan dan menerapkan metode pembelajaran yang bervariasi salah satunya adalah metode role playing pada peserta didik, karena berdasarkan keterangan guru PKn di SMP Muhammadiyah 3 dan 4 Kota Yogyakarta, metode yang digunakan setiap mengajar PKn adalah metode konvensional sedangkan metode yang lain jarang sekali digunakan termasuk metode role playing belum pernah diterapkan dalam pembelajaran $\mathrm{PKn}$, hal ini disebabkan karena guru menganggap metode konvensional lebih mudah dan simpel. Penulis merekomendasikan menggunakan metode role playing karena metode ini merupakan model pembelajaran sosial yang lebih menekankan pada hubungan sosial antara indivindu dengan orang lain (masyarakat).

Kompetensi Inti dan Kompetensi Dasar dijadikan acuan, maka guru PKn harus mampu mewujudkan langkah-langkah pembelajaran yang aktif, inovatif, kreatif, efektif, dan menyenangkan (PAIKEM), sehingga proses pembelajaran menjadi bermakna. Berbagai macam model pembelajaran yang dapat diterapkan diantaranya model pembelajaran langsung, pembelajaran aktif, model pembelajaran berdasarkan masalah dan lain-lain. Variasi model-model pembelajaran yang diterapkan guru diharapkan bisa menanamkan nilai-nilai Pancasila pada peserta didik agar menjadi warga negara yang baik dan bisa berguna bagi keluarga, agama, masyarakat, bangsa, dan negara. Berdasarkan hasil observasi pada hari Selasa, 16 September 2014 di SMP Muhammadiyah 4 Kota Yogyakarta, memperlihatkan bahwa beberapa peserta didik tidak memperhatikan penjelasan guru pada saat proses belajar mengajar. Hal ini dikarenakan kegiatan belajar mengajar hanya seputar mendengar, memperhatikan penjelasan, dan mencatat hal-hal yang disampaikan oleh guru (metode pembelajaran yang diterapkan oleh guru bersifat monoton). Peserta didik menjadi bosan mengikuti pembelajaran PKn. Oleh karena itu, guru harus berusaha menghidupkan suasana kelas agar peserta didik menjadi senang dan tertarik mengikuti pembelajaran PKn dengan memvariasikan metode pembelajaran yang digunakan. Selain itu, respons peserta didik juga sangat minim ketika guru memberikan stimulus. Hal ini terlihat ketika guru memberikan kesempatan bertanya kepada peserta didik, namun tidak ada satu pun yang mengajukan pertanyaan. Guru sendiri menjadi bingung dengan tidak adanya peserta didik yang bertanya apakah itu menunjukkan peserta didik sudah paham atau belum terhadap materi yang dijelaskan atau diajarkan.

Selain wawancara, penulis juga melakukan observasi pada hari Sabtu, 20 September 2014 di SMP Muhammadiyah 4 Kota Yogyakarta yang memperlihatkan bahwa beberapa peserta didik terlihat tidak bersemangat dalam mengikuti pelajaran. Kondisi seperti ini menuntut guru harus profesional, bisa mengemas dan menghidupkan suasana belajar (kelas) dengan aman, nyaman, dan kondusif. Alternatif yang dapat dilakukan guru agar peserta didik tidak ngantuk yaitu dengan menerapkan metode role playing, karena metode ini melibatkan peserta didik dalam proses belajar mengajar yaitu dengan bermain peran yang dapat mengaktifkan aspek kognitif, afektif, dan psikomotorik. Dengan melakukan aktivitas bermain peran maka peserta didik tidak akan ngantuk di dalam kelas. Pembelajaran kooperatif model role playing ini merupakan metode pembelajaran sosial yang lebih menekankan kerja sama dalam kelompok sehingga peserta didik harus dapat bekerja sama dengan teman-teman kelompoknya masing-masing tanpa memandang status sosial (kaya/miskin), jenis kelamin, dan kemampuan intelektual (kognitif). Metode role playing (bermain peran) merupakan metode yang bertujuan untuk mengaktifkan peserta didik dalam proses pembelajaran dan memberikan pengalaman langsung dengan memainkan peran sesuai dengan karakter tokoh yang ada dalam suatu cerita/naskah serta terjalinnya interaksi (komonikasi) antara peserta didik yang satu 
dengan peserta didik yang lain. Hal ini sesuai dengan pendapat Lickona (2012, p. 377) yang menjelaskan bahwa "metode role playing adalah metode yang paling efektif dalam merangsang minat dan keikutsertaan peserta didik". Dengan bermain peran maka semangat belajar peserta didik akan semakin kuat karena ikut terlibat langsung dalam situasi yang sebenarnya melalui peran yang dimainkan, apalagi Indonesia pada bulan Desember 2015 akan memasuki pasar bebas yang menuntut setiap orang bisa berperan/bersaing sesuai dengan tantangan zaman. Jadi, dapat disimpulkan bahwa metode role playing adalah suatu metode yang memperagakan karakter (sikap seseorang) sesuai dengan kondisi sosial sehingga peserta didik benar-benar menjiwai tokoh yang diperankannya.

Berdasarkan latar belakang masalah di atas, maka penulis tertarik untuk melakukan penelitian di SMP Muhammadiyah 3 dengan SMP Muhammadiyah 4 Kota Yogyakarta dengan judul "Keefektifan Metode Role Playing untuk Penanaman Nilai-nilai Pancasila pada Pembelajaran PKn". Dalam penelitian ini, SMP Muhammadiyah 3 Kota Yogyakarta penulis pilih sebagai kelas eksperimen dan SMP Muhammadiyah 4 Kota Yogyakarta sebagai kelas kontrol. Penulis memilih SMP Muhammadiyah 3 dan 4 Kota Yogyakarta sebagai tempat penelitian karena kedua sekolah ini setara dilihat dari peringkat hasil Ujian Nasional tahun 2013/2014.

\section{METODE}

Penelitian ini adalah penelitian eksperimen semu (Quasi Experiment). Pendekatan quasi eksperimen dipilih karena peneliti merancang pembelajaran Pendidikan Kewarganegaraan (PKn) menggunakan metode role playing yang belum diketahui keefektifannya untuk mengoptimalkan penanaman nilai-nilai Pancasila pada pembelajaran PKn dan untuk membandingkan keefektifan metode role playing dengan metode konvensional.

Desain penelitian yang digunakan dalam penelitian ini adalah Pretest-Posttes Control Group Design. Dalam desain ini terdapat dua kelompok yaitu kelompok eksperimen dan kelompok kontrol yang dipilih secara random, kemudian diberi pretest untuk mengetahui keadaan awal, apa ada perbedaan antara kelompok eksperimen dan kelompok kontrol. Kelompok eksperimen diberikan perlakuan, sedangkan kelompok kontrol tidak diberikan perlakuan (tetap menggunakan metode pembelajaran yang biasa digunakan guru yaitu metode ceramah dan tanya jawab), sama-sama diberikan observasi awal dan akhir. Pengadaan observasi awal dilakukan guna penyetaraan kemampuan peserta didik sebelum dilakukan penelitian. Gambarnya dapat dilihat sebagai berikut.

Tabel 1. Desain Penelitian

\begin{tabular}{cccc}
\hline $\mathbf{E}$ & $\mathbf{O 1}$ & $\mathbf{X 1}$ & $\mathbf{O 2}$ \\
\hline $\mathbf{K}$ & $\mathbf{O} 1$ & $\mathbf{X} 2$ & $\mathbf{O} 2$
\end{tabular}

Keterangan:

O1 : Tes awal untuk melihat kemampuan peserta didik sebelum treatment dilakukan

O2 : Tes akhir untuk melihat kemampuan akhir peserta didik setelah treatmen dilakukan

E : Kelas eksperimen (kelas yang menggunakan metode role playing

$\mathrm{K}$ : Kelas kontrol (kelas yang menggunakan metode konvensional)

$\mathrm{X} 1$ : Treatment menggunakan metode role playing pada kelas eksperimen

X2 : Treatment menggunakan metode konvensional pada kelas kontrol

Desain ini disebut randomized control group pre-test post-test desain, karena dalam desain ini kedua kelompok kelas diberi tes awal (pretest) dengan tes yang sama. Setelah treatment selesai dilakukan maka kedua kelompok diberikan tes yang sama sebagai tes akhir (posttest). Penggunaan model eksperimen ini dikarenakan untuk memberikan hasil yang mempunyai tingkat validitas maksimal. Dalam penelitian ini yang dieksperimenkan adalah metode role playing dibandingkan dengan metode konvensional. Dengan demikian, penelitian ini dilakukan dengan membandingkan dua perlakuan yang berbeda kepada subjek penelitian. Secara khusus penelitian ini dilakukan untuk mengetahui perbedaan penanaman nilai Pancasila (nilai kerakyatan) menggunakan metode role playing untuk kelas eksperimen dan penanaman nilai-nilai Pancasila menggunakan metode konvensional pada kelas kontrol. 
Penelitian ini dilakukan di SMP Muhammadiyah 3 dan 4 Kota Yogyakarta pada semester II tahun pelajaran 2014/2015. Penelitian ini dilaksanakan pada bulan Maret sampai dengan bulan April tahun pelajaran 2014/2015. Alasan pemilihan SMP Muhammadiyah 3 dan 4 Kota Yogyakarta sebagai tempat penelitian yaitu, kedua Sekolah tersebut merupakan Sekolah yang sederajat dilihat dari hasil Ujian Nasional tahun 2013/2014. SMP Muhammadiyah 3 Kota Yogyakarta mendapat peringkat ke 2 dan SMP Muhammadiyah 4 Kota Yogyakarta mendapat peringkat ke 3 dari 10 Sekolah SMP Muhammadiyah Kota Yogyakarta. Peneliti memilih sekolah yang berbeda supaya tidak menimbulkan subjektivitas pada guru, karena yang mengajar pada kelas VIII hanya satu guru.

Subjek penelitian ini adalah 32 peserta didik kelas VIII B SMP Muhammadiyah 3 Kota Yogyakarta (kelas eksperimen) dan 30 peserta didik kelas VIII A SMP Muhammadiyah 4 Kota Yogyakarta (kelas kontrol), sehingga keseluruhan subjek berjumlah 62 peserta didik. Penelitian ini terdiri dari satu variabel bebas (independent) dan satu variabel terikat (dependent). Variabel bebas dalam penelitian ini adalah metode role playing, sedangkan variabel terikat dalam penelitian ini adalah penanaman nilai-nilai Pancasila (nilai kerakyatan). Teknik pengumpulan data dalam penelitia ini yaitu dengan observasi, wawancara, dan angket (kuisioner). Teknik pengumpulan data adalah cara-cara yang digunakan untuk mengumpulkan data. Langkah-langkah pengumpulan data dalam penelitian adalah: 1.) Menyusun instrumen penelitian (silabus, RPP, kisi-kisi soal pretest dan posttest); 2.) Validasi instrumen penelitian, instrumen penelitian pada penelitian ini divalidasi oleh dua orang ahli; 3.) Memberikan pretest (tes prestasi atau materi kedaulatan rakyat, serta angket penanaman nilai-nilai Pancasila) kepada kelas eksperimen dan kelas kontrol; 4.) Memberikan perlakuan dengan pembelajaran role playing pada kelas eksperimenl; dan 5.) Mengumpulkan data setelah perlakuan diberikan dengan memberikan posttest prestasi atau materi kedaulatan rakyat dan angket penanaman nilai-nilai Pancasila. Instrumen yang digunakan dalam penelitian ini adalah tes prestasi atau materi kedaulatan rakyat dan angket penanaman nilai-nilai Pancasila. Validitas instrumen penelitian merupakan ketepatan mengukur apa yang seharusnya diukur oleh item-item yang ada pada instrumen. Uji validitas instrumen tes dan non tes pada penelitian ini menggunakan validitas isi dengan expert judgemen.

Teknik analisis data dalam penelitian ini meliputi dua analisis, yakni analisis deskriptif dan analisis inferensial (uji hipotesis). Data penelitian yang dianalisis adalah data tes materi kedaulatan rakyat dan angket penanaman nilai-nilai Pancasila sebelum (pretest) dan setelah (posttest) diberikan perlakuan. Data pretest bertujuan untuk mengetahui gambaran awal kelas eksperimen dan kelas kontrol. Selanjutnya, data tes kedaulatan rakyat dan angket penanaman nilai-nilai Pancasila setelah diberikan perlakuan digunakan untuk mendeskripsikan keefektifan model pembelajaran role playing dibandingkan dengan model pembelajaran konvensional pada peserta didik kelas VIII di SMP Muhammadiyah 3 dan SMP Muhammadiyah 4 Kota Yogyakarta. Analisis inferensial (uji hipotesis) dengan terlebih dahulu melakukan uji persyaratan analisis atau uji asumsi yang meliputi uji normalitas, uji homogenitas, dan uji hipotesis. Uji normalitas bertujuan untuk mengetahui apakah data yang ada berdistribusi normal atau tidak. Dalam penelitian ini uji normalitas dilakukan terhadap skor tes materi kedaulatan rakyat dan angket penanaman nilai-nilai Pancasila baik untuk pretestt maupun posttestt pada kedua kelompok. Uji ini dilakukan sebagai syarat sebelum melakukan analisis dengan uji two-group Multivariat Analysis of Variance (MANOVA).

Uji homogenitas bertujuan untuk mengetahui apakah data pada kelompok eksperimen dan kontrol mempunyai matriks varian-kovarians yang sama atau tidak. Uji homogenitas dilakukan terhadap skor tes kedaulatan rakyat dan angket penanaman nilai-nilai Pancasila pretest maupun posttest. Untuk mengetahui tingkat homogenitas matriks kovarians dilakukan dengan menggunakan uji Box-M dengan menggunakan bantuan program SPSS 16.0 for windows. Analisis data dalam penelitian ini menggunakan analisis inferensial untuk menguji hipotesis penelitian, sehingga sebelum di uji hipotesis terlebih dahulu disusun hipotesis nol (H0) dan hipotesis alternatif (Ha). H0 ditolak apabila nilai signifikan yang diperoleh lebih kecil dari 0,05 , sedangkan $\mathrm{H} 0$ diterima apabila nilai signifikan yang diperoleh lebih besar dari 0,05 . Selanjutnya, pengujian hipotesis kedua penelitian ini menggunakan uji MANOVA. Hal ini bertujuan untuk mengetahui apakah metode role playing lebih efektif untuk meningkatkan penanaman nilai-nilai Pancasila pada pembelajaran PKn dibandingkan dengan metode konvensional yang diterapkan di SMP Muhammadiyah 4 Kota Yogyakarta. Dalam penelitian ini, peneliti melakukan analisis dengan bantuan program SPSS 16.0 for windows. 


\section{HASIL DAN PEMBAHASAN}

Deskripsi data ini menguraikan tentang data keefektifan metode role playing dan penanaman nilai-nilai Pancasila (nilai kerakyatan). Data ini diperoleh dari penelitian eksperimen pembelajaran PKn dengan menggunakan metode role playing pada kelas eksperimen dan metode konvensional pada kelas kontrol.

Data prestasi belajar (materi kedaulatan rakyat)

Data prestasi belajar peserta didik sebelum dan setelah diberikan perlakuan metode role playing dan konvensional menyangkut tentang skor rerata (mean), skor minimum dan skor maksimum dapat dilihat pada Tabel 2. Pada Tabel 2 menunjukkan bahwa rata-rata skor pretest ke posttest untuk kelas eksperimen dan kelas kontrol secara umum mengalami peningkatan. Nilai minimum dan nilai maksimum yang dimaksud pada tabel tersebut adalah data perolehan peserta didik yang terdiri dari pretest dan posttest. Mengacu pada kriteria ketuntasan hasil belajar, rata-rata perolehan hasil belajar peserta didik setelah belajar menggunakan model atau metode pembelajaran role playing telah memenuhi Standar Ketuntasan Minimum (KKM) yang ditetapkan di Sekolah yaitu 75.

Tabel 2. Skor Rata-rata, Skor Maksimum Teoretik, Skor Minimum Teoretik Prestasi Belajar Peserta didik Sebelum dan Setelah Perlakuan

\begin{tabular}{lcccc}
\hline \multicolumn{1}{c}{ Prestasi } & \multicolumn{2}{c}{ Eksperiman } & \multicolumn{2}{c}{ Kontrol } \\
& Pretest & Posttest & Pretest & Postest \\
\hline Rata-rata & 53,5 & 79,13 & 68,27 & 75 \\
Skor maksimum teoretik & 100,00 & 100,00 & 100,00 & 100,00 \\
Skor minimum teoretik & 0,00 & 0,00 & 0,00 & 0,00 \\
Skor maksimum peserta didik & 92 & 92 & 92 & 96 \\
Skor minimum peserta didik & 24 & 60 & 52 & 56 \\
\hline
\end{tabular}

Data Penanaman Nilai-nilai Pancasila

Data hasil angket penanaman nilai-nilai Pancasila yang dideskripsikan terdiri dari data pretest dan posttest. Pretest merupakan tes yang diberikan pada kedua kelompok (eksperimen dan kontrol) sebelum dilaksanakannya treatment. Pemberian angket penanaman nilai Pancasila ini bertujuan untuk mengetahui nilai Pancasila peserta didik sebelum treatment. Posttest diberikan setelah treatment dilaksanakan. Pemberian angket penanaman nilai-nilai Pancasila pada peserta didik bertujuan untuk mengetahui nilai-nilai Pancasila peserta didik setelah diberikan treatment. Pendeskripsian dan pengkategorian nilai Pancasila peserta didik pada penelitian ini mengacu pada rumus yang dikembangkan oleh Azwar (2000, p. 36) yang dapat dilihat pada Rumus 1. Adapun data angket penanaman nilai-nilai Pancasila sebelum dan setelah diberikan treatment dapat dilihat pada Tabel 3.

Tabel 3. Skor Rata-rata, Skor Maksimum Teoretik, Skor Minimum Teoretik Nilai-nilai Pancasila Sebelum dan Setelah Perlakuan

\begin{tabular}{lcclc}
\multirow{2}{*}{ Nilai-nilai Pancasila } & \multicolumn{2}{c}{ Eksperimen } & Kontrol \\
& Pretest & Posttest & Pretest & Posttest \\
\hline Rata-rata & 62,25 & 68,3 & 57,7 & 79,0 \\
Skor maksimum teoretik & 100 & 100 & 100 & 100 \\
Skor minimum teoretik & 25 & 25 & 25 & 25 \\
Skor maksimum peserta didik & 77 & 78 & 70 & 89 \\
Skor minimum peserta didik & 46 & 56 & 43 & 70 \\
\hline
\end{tabular}

Berdasarkan Tabel 3 dapat dilihat bahwa rata-rata skor pretest ke posttest untuk kelas eksperimen dan kelas kontrol secara umum mengalami peningkatan. Nilai minimum dan nilai 
maksimum yang dimaksud adalah skor yang diperoleh peserta didik dalam mengisi angket pada saat pretest dan posttest. Sesuai dengan hasil penelitian ini bahwa metode role playing efektif untuk menanamkan nilai-nilai Pancasila yaitu nilai kerakyatan. Hal ini sesuai dengan pembuktian hipotesis yang telah dilakukan.

$$
r_{x y}=\frac{N \sum X . Y-\left(\sum X\right) \cdot\left(\sum Y\right)}{\sqrt{\left(N \cdot \sum X^{2}-\left(\sum X^{2}\right)\right) \cdot\left(N \cdot \sum Y^{2}-\left(\sum Y^{2}\right)\right)}}
$$

\section{Keefektifan Metode Role Playing untuk Penanaman Nilai-nilai Pancasila}

Keefektifan metode role playing dalam meningkatkan prestasi dan penanaman nilai-nilai Pancasila peserta didik di SMP Muhammadiyah 3 Kota Yogyakarta dapat dilihat dari hasil ulangan harian, ujian tengah semester, dan ujian akhir semester. Apabila Kriteria Ketuntasan Minimal (KKM) sudah tercapai, maka suatu metode bisa dikatakan efektif. Kriteria Ketuntasan Minimum (KKM) yang telah ditentukan oleh SMP Muhammadityah 3 dan SMP Muhammadiyah 4 Kota Yogyakarta untuk kelas VIII yaitu 75. Peserta didik dikatakan berhasil apabila secara klasikal memperoleh nilai minimal 75. Selanjutnya, diuji dengan menggunakan uji statistik one sampel t-test dengan tujuan untuk melihat keefektifan masing-masing metode pembelajaran ditinjau dari aspek prestasi dan nilainilai Pancasila peserta didik pada pembelajaran PKn. Hal ini relevan dengan penjelasan Faiq (2015) yang mengemukakan bahwa beberapa ciri suatu metode dikatakan efektif yaitu: 1.) Mengembangkan pemahaman peserta didik terhadap materi pelajaran; 2.) Membuat peserta didik memiliki rasa ingin tahu; 3.) Membuat peserta didik menjadi tertantang, dapat membuat peserta didik aktif secara mental, fisik, dan psikis; serta 5.) Membantu peserta didik tumbuh kreatif, dan mudah dilaksanakan oleh guru.

Selain itu, hasil penelitian yang dilakukan Zidniyati (2009, pp. 162-163) mengemukakan bahwa penggunaan metode bermain peran dapat meningkatkan hasil belajar pendidikan nilai peserta didik dan penggunaan metode bermain peran dapat meningkatkan hasil belajar pendidikan keterampilan berbahasa Indonesia peserta didik. Dengan demikian, metode bermain peran efektif untuk pendidikan nilai dan keterampilan berbahasa yang terintegrasi dalam pembelajaran Bahasa Indonesia. Faktor lain yang mendukung keefektifan metode role playing adalah suasana kelas yang kondusif (bersih, nyaman, dan aman) dengan pantauan guru yang berwibawa (disegani) oleh peserta didik, fasilitas kelas yang mendukung seperti LCD proyektor, buku paket dan LKS. Berdasarkan hasil uji statistik menunjukkan bahwa metode role playing efektif dalam meningkatkan prestasi belajar peserta didik dan penanaman nilai-nilai Pancasila pada peserta didik. Metode pembelajaran yang diterapkan pada kelas eksperimen (role playing) selama kegiatan pembelajaran berlangsung membuat peserta didik senang dan bersemangat dalam mengikuti proses pembelajaran. Kondisi tersebut dapat tercipta karena pada proses pembelajaran dengan menggunakan metode role playing, setiap individu mempunyai kesempatan dalam menyalurkan ide dan argumennya masing-masing. Hal yang tidak kalah pentingnya adalah setiap peserta didik memiliki tanggung jawab terhadap diri mereka sendiri dalam mengikuti proses pembelajaran. Tanggung jawab ini secara tidak langsung menumbuhkan adanya kesadaran pada setiap individu untuk mencapai prestasi belajar.

Keefektifan Metode Konvensional untuk Penanaman Nilai-nilai Pancasila

Keefektifan pembelajaran konvensional pada peserta didik di SMP Muhammadiyah 4 Kota Yogyakarta dapat diketahui dari hasil uji one sampel t-test. Hasil uji one sampel t-test menunjukkan bahwa pembelajaran konvensional efektif ditinjau dari penanaman nilai-nilai Pancasila peserta didik, namun tidak efektif ditinjau dari prestasi belajarnya. Kondisi ini terjadi karena pada saat pengisian angket peserta didik sangat fokus dan tidak ada yang main-main. Namun, selama proses pelaksanaan pembelajaran, tidak semua peserta didik dapat maksimal dengan metode ceramah. Peserta didik menjadi pasif, hal ini dikarenakan peserta didik hanya mendengarkan ceramah yang disampaikan oleh guru selama proses belajar mengajar. Selain itu, metode konvensional lebih menekankan pada hasil dibandingkan dengan proses, sehingga materi yang diperoleh atau diajarkan menjadi mudah dilupakan oleh peserta didik. Hal ini turut menjadikan peserta didik merasa jenuh dalam mengikuti 
proses pembelajaran yang berdampak pada hasil capaian belajarnya. Faktor lain yang mempengaruhi tidak efektifnya metode konvensional ditinjau dari prestasi peserta didik adalah tidak diimbanginya ceramah dengan alat yang memadai seperti proyektor atau perangkat multimedia lainnya. LCD proyektor yang ada di kelas VIII A SMP Muhammadiyah 4 Kota Yogyakarta tidak berfungsi atau rusak, sehingga peserta didik hanya mendengarkan dan mencatat apa yang disampaikan oleh guru. Setiap guru yang akan mengajar senantiasa dihadapkan pada pilihan metode. Banyak macam metode yang bisa dipilih guru dalam kegiatan mengajar, namun tidak semua metode bisa dipilih guru dalam kegiatan mengajar. Dan tidak semua metode dikatakan jelek. Kebaikan suatu metode terletak pada ketetapan memilih sesuai dengan tuntutan pembelajaran.

Perbedaan Keefektifan antara Metode Role Playing dengan Metode Konvensional untuk Penanaman Nilai-nilai Pancasila

Hipotesis ini menyatakan bahwa terdapat perbedaan antara peserta didik yang mengikuti pembelajaran PKn dengan metode role playing dan peserta didik yang mengikuti pembelajaran PKn dengan metode konvensional. Dalam pelaksanaanya yang diperkuat oleh hasil uji statistik menunjukkan bahwa peserta didik yang belajar dengan menggunakan metode role playing lebih efektif apabila ditinjau dari hasil prestasi dan penanaman nilai-nilai Pancasila dibandingkan dengan peningkatan hasil tes PKn di kelas kontrol. Metode role playing lebih efektif dari metode konvensional karena metode role playing merefleksikan tentang materi pelajaran secara nyata. Dengan kata lain, peserta didik diajak untuk terlibat secara langsung untuk memerankan tokoh yang ada dalam materi pembelajaran tersebut, serta alur atau peristiwa yang ada di dalamnya. Dengan demikian, maka peserta didik lebih mudah untuk memahami dan menganalisa kejadian yang ada dalam materi pelajaran, karena langsung diperlihatkan dan diperankan dalam bentuk role playing (bermain peran). Hal ini sejalan dengan apa yang dikemukakan oleh Joyce dan Weil (1996, p. 92) yang menyatakan bahwa the role playing process provides a live sample of human behaviour that serves as a vehicle for students to: 1.) explore their feelings; 2.) gain insight into their attitudes, values, and perceptions; 3.) develop their problem solving skills and attitudes; and 4.) explore subject matter in varied way.

Alasan lain metode role playing lebih efektif untuk penanaman nilai-nilai Pancasila (nilai kerakyatan) pada peserta didik, karena dalam metode role playing terdapat peran dan tugas yang harus dijalankan oleh peserta didik selama role playing (bermain peran) berlangsung. Dalam proses role playing, masing-masing peserta didik melaksanakan tugas dan kewajiban mereka sebagai anggota dari sebuah kelompok. Dalam hal ini, peserta didik memperhatikan nilai Pancasila (nilai kerakyatan) dalam kelompok dan juga dalam kelas, karena peserta didik yang memainkan peran adalah peserta didik yang dipercaya oleh guru dan peserta didik lainnya, sehingga mereka harus menjalankan peran mereka dengan sebaik-baiknya. Bermain peran tentang "Kedaulatan Rakyat" yang di dalamnya terdapat tokoh-tokoh yang diperankan oleh peserta didik. Jadi, peserta didik tidak hanya menghafal tetapi bisa menghayati peran-peran tokoh dalam peristiwa tersebut kemudian diambil makna atau nilai yang terkandung di dalamnya yaitu nilai kerakyatan dari para tokoh tersebut. Berdasarkan hasil penelitian ini, jelas bahwa penggunaan metode role playing dalam pembelajaran PKn lebih efektif untuk penanaman nilai-nilai Pancasila pada peserta didik dibandingkan dengan pembelajaran PKn yang mengunakan metode konvensional. Ini berarti pembelajaran PKn yang dilaksanakan dengan metode role playing dalam materi "Kedaulatan Rakyat" memiliki pengaruh yang lebih besar terhadap penanaman nilai-nilai Pancasila pada peserta didik dibandingkan dengan pembelajaran PKn yang menggunakan metode konvensional. Dengan kata lain bahwa pengintegrasian penanaman nilai-nilai Pancasila ke dalam materi dan proses pembelajaran PKn dapat membuat pembelajaran lebih bermakna, tidak hanya sekedar pencapaian kognitif saja tetapi afektif dan juga psikomotorik.

\section{SIMPULAN}

Berdasarkan hasil analisis dan pembahasan, maka dapat disimpulkan beberapa hal sebagai berikut: 1.) Metode role playing efektif untuk penanaman nilai-nilai Pancasila pada pembelajaran Pendidikan Kewarganegaraan (PKn); 2.) Metode konvensional efektif untuk penanaman nilai-nilai 
Pancasila pada pembelajaran Pendidikan Kewarganegaraan (PKn); dan 3.) Metode role playing lebih efektif dibandingkan dengan metode konvensional untuk penanaman nilai-nilai Pancasila pada pembelajaran Pendidikan Kewarganegaraan (PKn).

Penelitian ini mendeskripsikan keefektifan metode role playing dan pembelajaran konvensional ditinjau dari penanaman nilai-nilai Pancasila pada peserta didik SMP Muhammadiyah 3 dan SMP Muhammadiyah 4 Kota Yogyakarta. Berdasarkan simpulan di atas, dapat dikemukakan implikasi secara teoretis dan praktis dari hasil penelitian ini. Adapun impilkasi dari hasil penelitian ini adalah sebagai berikut: 1.) Hasil penelitian ini menunjukkan bahwa penggunaan metode role playing efektif untuk penanaman nilai-nilai Pancasila pada pembelajaran PKn. Hal ini memberikan suatu indikasi bahwa penggunaan metode role playing dalam pembelajaran PKn lebih tepat diterapkan daripada pembelajaran PKn yang menggunakan metode konvensional. Penerapan metode role playing dalam pembelajaran PKn berimplikasi terhadap perencanaan dan pengembangan model atau metode pembelajaran; dan 2.) Hasil penelitian ini dapat dijadikan sebagai bahan pertimbangan bagi para guru, terutama guru mata pelajaran PKn, agar lebih memperhatikan kebutuhan peserta didik. Peserta didik membutuhkan pendekatan yang lebih variatif dan melibatkan peserta didik secara lebih aktif, sehingga pembelajaran PKn menjadi lebih bermakna dan menyenangkan. Di samping itu, dengan diperkenalkan nilai-nilai Pancasila yang terkandung dalam materi pelajaran, pembelajaran menjadi lebih bermakna. Oleh karena itu, dengan penggunaan metode role playing dalam pemberlajaran PKn peserta didik bisa merasakan secara langsung makna dari pelajaran itu dalam dirinya, dalam hal ini bimbingan guru sangat diperlukan. Peserta didik dibimbing untuk menemukan apa makna yang bisa dipetik dari sebuah pembelajaran di kelas untuk kehidupan mereka di masyarakat. Dengan metode role playing, maka materi PKn akan menjadi lebih kontekstual dan lebih konkrit.

\section{DAFTAR PUSTAKA}

Amir, S. (2013). Pancasila as integration philosophy of education and national character. International Journal of Scientific \& Technology Research, 2(1), 54-57.

Calm, C., \& Sobirin, S. (2012). Memperkokoh nilai-nilai Pancasila. Jurnal Internasional, 14, 98.

Faiq, M. (2015, February 1). Ciri-ciri metode mengajar yang efektif. Retrieved from http://penelitiantindakankelas.blogspot.com/2013/01/cirimetode-mengajar-yangefektif.html

Hamidi, J. \& Lutfi, M. (2010). Civic education: antara realitas politik dan implementasi hukumnya. Jakarta: Gramedia Pustaka Utama.

Joyce \& Weil. (1996). Models of teaching (4th ed.). London: Allyn \& Bacon.

Lickona, T. (2012). Educating for character: mendidik untuk membentuk karakter. Jakarta: Bumi Aksara.

Putra, R.M.S. (2010). Etika dan tertib hidup berwarga negara. Jakarta: Penerbit Salemba Humanika.

Romli, R. (2012). Pancasila sebagai landasan dalam kehidupan bernegara, berbangsa, dan bermasyarakat (perspektif makna komprehensif) (Unpublished master's thesis). Universitas Islam Indonesia, Indonesia.

Sukadi, S. (2010). Pemahaman dan orientasi nilai Pancasila mahasiswa sebagai wahana pendidikan karakter bangsa. Jurnal Pendidikan dan Pengajaran, 43(3), 263-273. doi: http://dx.doi.org/10.23887/jppundiksha.v43i3.131

Zidniyati, Z. (2009). Keefektifan metode bermain peran untuk pendidikan nilai dan pembelajaran keterampilan berbahasa Indonesia di Madrasah Ibtidaiyah (Unpublished master's thesis). Universitas Negeri Yogyakarta, Indonesia. 